\author{
O.V. Stepin ${ }^{1}$, I.A. Gryshko ${ }^{2 *}$ \\ 1"BOEING Ukraine" LLC, Kyiv, Ukraine \\ ${ }^{2}$ Igor Sikorsky Kyiv Polytechnic Institute, Kyiv, Ukraine \\ *corresponding author: Griwko@ukr.net
}

\title{
SYSTEM OF DUAL TRAINING OF ENGINEERING PERSONNEL FOR KNOWLEDGE-BASED ENTERPRISES AND HIGH-TECH INDUSTRIES
}

\begin{abstract}
Background. Nonconformity of training of qualified engineers for high-tech companies with the requirements of hightech manufacturing industries in Ukraine.
\end{abstract}

Objective. The purpose of the paper is to develop a three-stage system of dual education for Igor Sikorsky Kyiv Polytechnic Institute and companies "Boeing Ukraine" and "Progresstech-Ukraine" that will be focused on efficient trainings of future technicians to solve applied engineering and technological tasks for the above-mentioned companies.

Methods. Analysis of successful cooperation of Igor Sikorsky Kyiv Polytechnic Institute, "Boeing Ukraine" and "Progresstech-Ukraine" aircraft corporations in the sphere of implementation of higher education concepts using dual form of education.

Results. It is shown that the implementation of the dual education for graduate students, where theoretical studies are augmented by solution of applied engineering problems will boost the number of high-skilled engineers available for hire by hi-tech companies. The advantages of dual education for both sides of recruiting process are discussed. It is noted that the implementation of dual education in universities has a complex multi-level structure, where the role of the instructor and the teacher should be treated as one of the most important one. A recent success in the cooperation between the Igor Sikorsky Kyiv Polytechnic Institute, the "Boeing Ukraine" and "Progresstech-Ukraine" shows the advances and the achievements in higher education driven by the dual education strategy.

Conclusions. System analysis of engineering and technological problems of aviation companies of Ukraine showed that the qualification of the graduates does not meet the requirements of high-tech companies. Therefore, the main goal of a multi-layer dual education, that was jointly developed by Igor Sikorsky Kyiv Polytechnic Institute, "Boeing Ukraine" and "Progresstech-Ukraine", is to train qualified specialists for the solution of everyday practical and technological tasks that are common for "Boeing Ukraine" and "Progresstech-Ukraine". Cooperation of Igor Sikorsky Kyiv Polytechnic Institute, "Boeing Ukraine" and "Progresstech-Ukraine" was launched in 2012. Since that time, more than 130 Igor Sikorsky Kyiv Polytechnic Institute graduates have become engineers of these corporations. Joint dual education master's degree "Dynamics and Strength of Machines" was certified by European Network for Accreditation of Engineering Education (ENAEE). The broadening of the three-level system of dual education offered by Igor Sikorsky Kyiv Polytechnic Institute, "Boeing Ukraine" and "Progresstech-Ukraine" to the multi-disciplinary level has a good potential and will be beneficial not only for the educational institutions but also for the high-tech companies.

Keywords: dual form of higher education; system of dual education; higher education institutions; aviation engineers; high-tech industry.

\section{Introduction}

The national development and the well-being of people depends directly on the economic growth of the state, which cannot be achieved without the development of high-tech industries. To achieve success, big multinational companies always focused on the implementation of new intelligent technologies, which, in its turn, were developed by qualified engineering and technical personnel. Higher education institutions are the main suppliers of qualified personnel to the labor market. Thus, the well-being of people in the state and state's economic development depend directly on the appropriate level of engineering personnel training in close relationship with high-tech business [1].
Training specialists given the rapid growth of production automation with a deep penetration of digital technologies into all components of the technological cycle of a product's life requires permanent improvement and adjustment of the university's academic curricula and training programs in view of real needs of the industry [2, 3].

Traditionally, academic programs for training engineers in higher educational institutions provide for acquisition of basic theoretical knowledge in the relevant subject and acquisition of practical skills by students. But only the combination of these two components on the basis of harmonized interaction between universities and high-tech companies makes it possible to train highly qualified and, above all, competitive specialists in the labor market [4-7]. 
Despite permanent attempts to reform legislation in the field of education in Ukraine, it has not yet been possible to achieve significant positive changes in the system of training engineering personnel, except for some specializations in the IT industry. This is due to a number of problems that have accumulated over the past decades. They consist, first of all, in the lack of a modern material and technical base in universities, increasing personnel shortage and insufficient level of collaboration between higher education institutions and the labor market [8]. These problems are not new, and it is impossible to quickly resolve them, but the labor market requires young specialists even today who are well versed in their branch and possess the necessary professional skills and abilities.

\section{Problem statement}

Scope of work: To develop a three-stage system of dual education for Igor Sikorsky Kyiv Polytechnic Institute and companies "Boeing Ukraine" and "Progresstech-Ukraine" that will be focused on efficient trainings of future technicians to solve applied engineering and technological tasks for the above-mentioned companies.

\section{Main principles of dual, innovative personnel training}

One of the ways to solve this problem is to implement the dual form of higher education [9]. This form of innovative training of specialists is complex (Fig. 1). The joint work of universities and companies on the development of each component of the innovative training of specialists allows meeting the market needs, as the first thing. And this contributes to the development of both the university and the partner enterprise.

The dual form of engineering education gives advantages to each participant in the educational process.

For a student:

- strong motivation, a sense of responsibility, the ability to work in a team of professionals, realization of personal potential in profession;

- work on real projects concerning current scientific and engineering problems while studying and training, work on course and diploma projects basing on the real company projects;

- obtaining practical skills, qualifications, mastering particular specialties;

- financial support for students during training and targeted employment in line with the specialty after graduation from the university.

For the University:

- use of modern material and technical base of enterprises;

- providing students with a place for traineeship;

- involvement of leading specialists of enterprises into the educational process;

- employment of a graduate in accordance with his/her specialty:

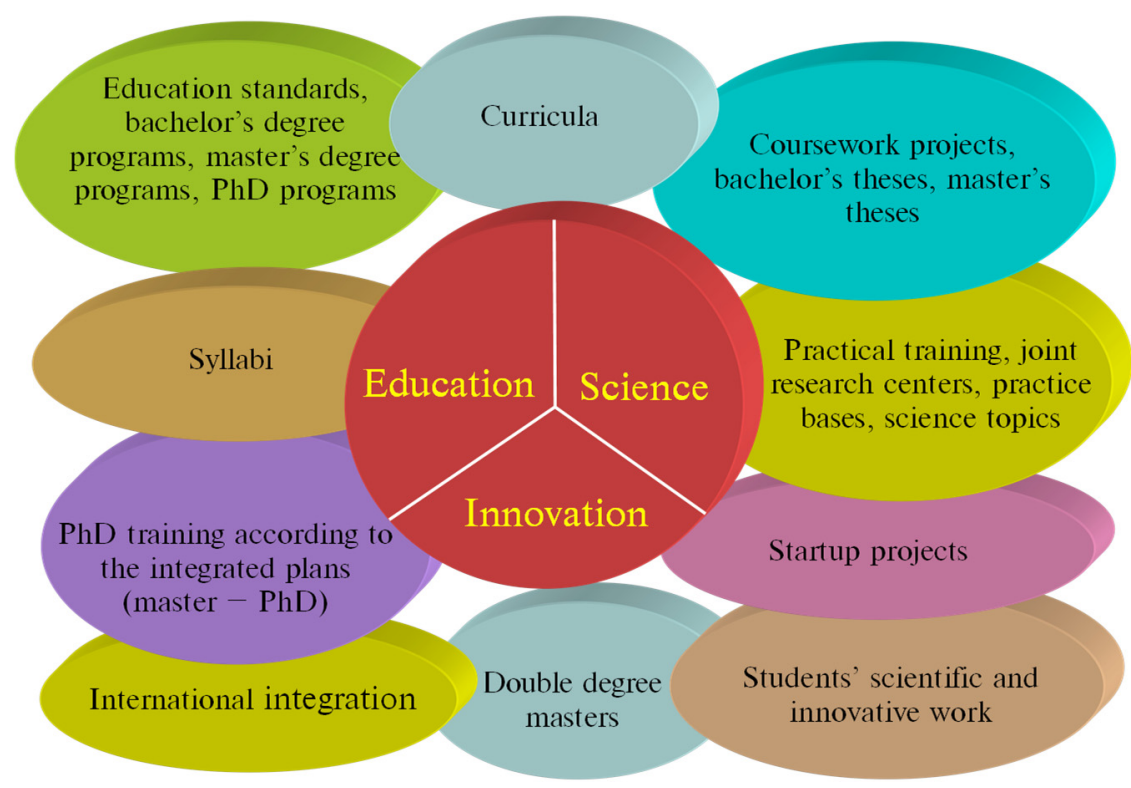

Fig. 1. Components of dual innovative trainings of specialists for high-tech industries 
- improving the University's ranking;

- development of modern methodological support of the educational process;

- transfer of a part of costs for practical training of specialists to the enterprise - strategic partner.

For the enterprise:

- high-quality and timely staff;

- the possibility of competitive selection of personnel during their studies at the University;

- early adaptation of the future employee to the specific needs of the enterprise;

- the possibility to correct educational programs for covering the production needs of its professional activity;

- shortening the cycle of training and retraining of high-quality specialists.

It is impossible to organize the formation of a highly qualified engineer who is able to work independently, make informed decisions based on the knowledge and experience he has acquired in four years of bachelor's and two years of master's degree program and this process can last for decades [10]. Implementation of the dual form of training permits to significantly shorten the training cycle, reduce the possible risks of the enterprise due to insufficient competence of the engineering staff and their incomplete knowledge of the specifics of the particular production.

\section{"Boeing Ukraine - Progresstech-Ukraine - KPI" system of dual form of training of aviation engineers}

To reduce these risks, the teaching staff plays an important role in the formation of a future engineer. It is possible to increase their competence and help them to gain real practical experience within the dual education framework. This is another level of the three-stage training of specialists:

At the first stage, the work is carried out to involve and select motivated youth (applicants).

At the second stage, the process of teaching students is effectuated according to the University academic programs and includes their work on real projects of the partner enterprise.

At the third stage, the feedback is provided by involving the teaching staff in real projects of the partner enterprise. This enables the professor to study in more detail the specifics and features of work at a particular enterprise, which in its turn allows adjusting the curricula in view of production needs and improve the quality of teaching.

This system is implemented within the framework of the dual education program launched by the Igor Sikorsky Kyiv Polytechnic Institute, "Boeing Ukraine" and "Progresstech-Ukraine" aircraft corporations (Fig. 2).

In accordance with the provisions on the dual form of higher education in the Igor Sikorsky Kyiv

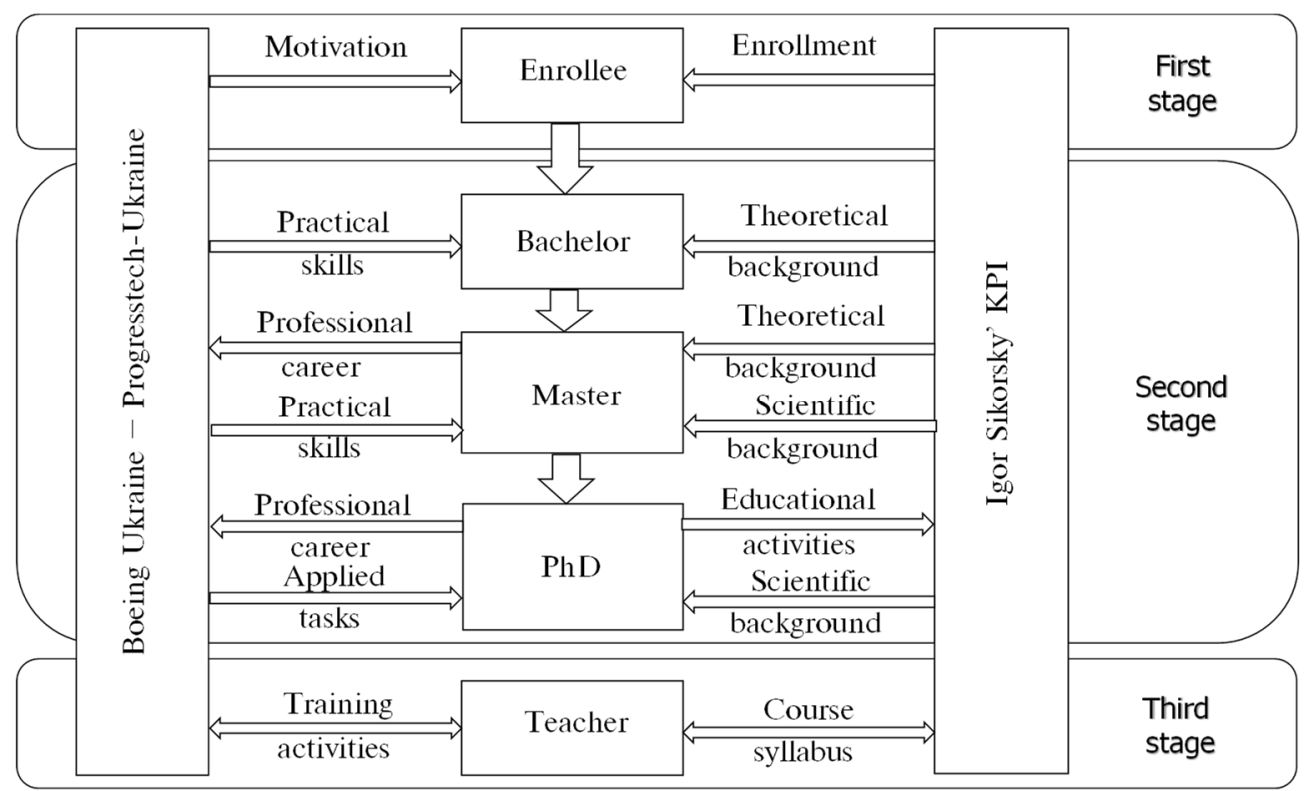

Fig. 2. Three-staged dual education system of Igor Sikorsky Kyiv Polytechnic Institute, "Boeing Ukraine” and "Progresstech-Ukraine" 
Polytechnic Institute [11], the main tasks of the dual form of higher education are:

- improving the practical component of the educational process while maintaining a sufficient level of theoretical training;

- improving the quality of specialist training in accordance with the actual requirements of the labor market;

- strengthening the role of employers and professional associations in the system of training qualified personnel: from the formation of the content of educational programs to the assessment of learning outcomes;

- modernization of the syllabus in order to bring it in line with the modern content of professional activity;

- increasing the level of competitiveness of University graduates in the context of globalization;

- reducing the period of adaptation of graduates to their professional activities.

- increasing the learning motivation among the applicants for higher education.

Cooperation of the technical university, "Boeing Ukraine" and "Progresstech-Ukraine" corporations began in 2012 when the agreement between Igor Sikorsky Kyiv Polytechnic Institute and "Progresstech-Ukraine" was signed. Since that time, more than 130 Igor Sikorsky Kyiv Polytechnic Institute graduates (Fig. 3) have become engineers of these corporations [12].

The students involved in the dual form of higher education, have the opportunity to solve applied and, above all, actual engineering problems in the engineering design, strength analysis and automation of systems of modern aircraft.
To increase the competitiveness in the labor market, specialists in the field of aircraft construction need to permanently improve their competence, continue to learn and acquire new knowledge. Therefore, universities must quickly respond to changes in labor market requirements by updating curricula, considering national and international standards for higher education quality, launching interdisciplinary programs, and providing students with the opportunity to draw up an individual learning path.

An important step forward was the procedure of independent European accreditation of the dual educational program for the master's degree in "Dynamics and Strength of Machines", which was carried out in June 2019 at Igor Sikorsky Kyiv Polytechnic Institute in close collaboration with the "Boeing Ukraine" and "Progresstech-Ukraine" corporations.

Accreditation was carried out by the Accreditation Commission of Universities of Technology of the European Network for Accreditation of Engineering Education (ENAEE).

The accreditation procedure was carried out in accordance with the ENAEE's standards and criteria, which contribute to the formation of common understanding of learning and teaching quality among all interested parties around the world, despite the national peculiarities of their higher education systems.

As a result of accreditation, Igor Sikorsky Kyiv Polytechnic Institute received the Certificate EURACE® Label ENAEE (Fig. 4), confirming the high quality of the "Dynamics and Strength of Machines" engineering educational program, developed in

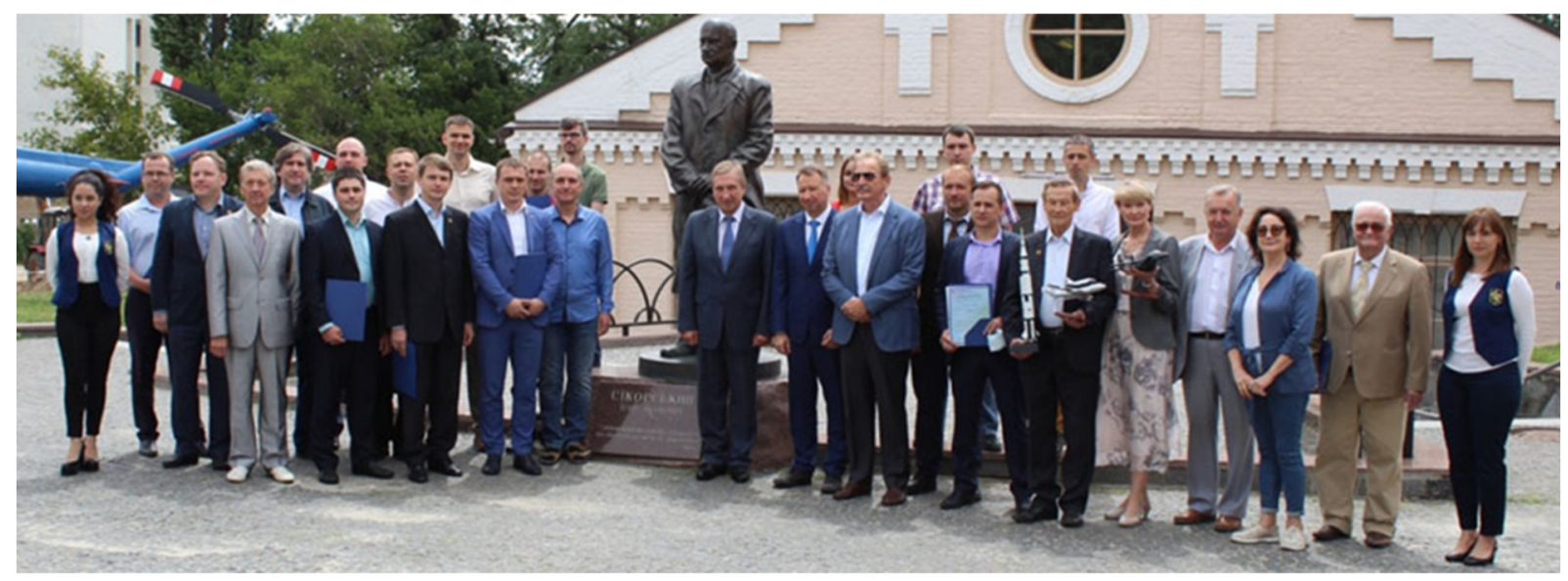

Fig. 3. The first group of professors trained to teach according to the dual training program, May 2020 
cooperation with "Boeing Ukraine" and "Progresstech-Ukraine" corporations.

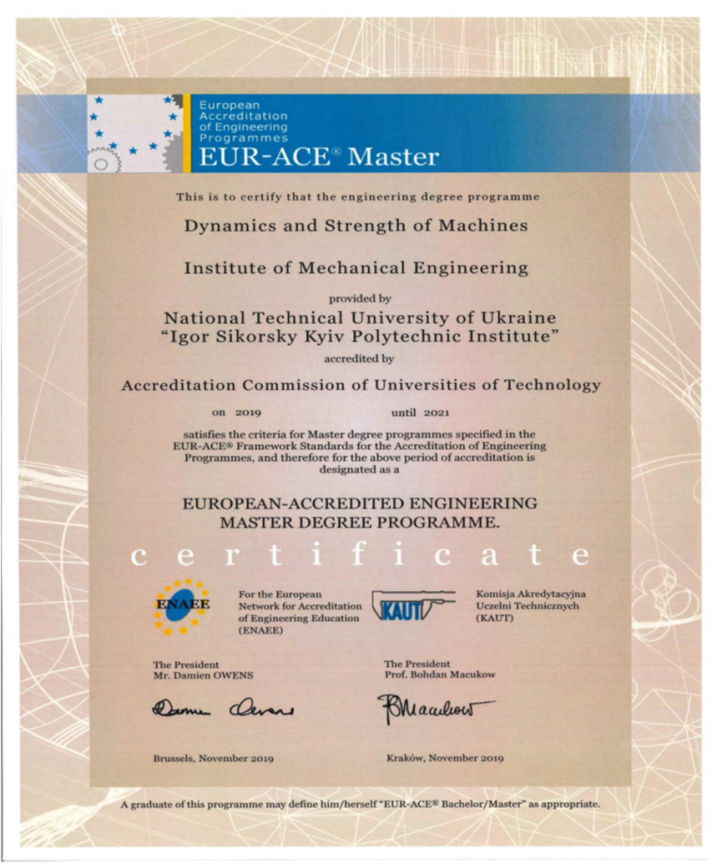

Fig. 4. Certificate of independent European accreditation of the "Dynamics and Strength of Machines" dual educational program "BOEING UKRAINE - PROGRESSTECHUKRAINE - KPI"

\section{Practical component of the system of dual train- ing of aviation engineers}

The training of engineering personnel, especially for science-driven industries, that should include aeronautic engineering, provides for the all- round and multifaceted enhancement of a future engineer. Indeed, in his daily work, the engineer has to perform a system analysis of engineering and technological problems needed to be solved. It means that the engineer must be a professional in his field, should be able to analyze existing engineering solutions and to come up with innovative solutions to the existing problems. And the practical experience is an inevitable in order to solve the abovementioned tasks.

All these skills and abilities are acquired by combining the efforts of the students, professors, and mentors during training.

To improve professional skills, the students in dual education system are required to work on real projects of a partner enterprise under the permanent supervision of a mentor.

Students are given real-life tasks to design a specific aircraft element (Fig. 5). It does not matter what kind of element it is. It may be an interior wall under the influence of inertial loads and internal pressure, or the cockpit doors, or door edging, ventilation grill, fasteners. There is not a single unimportant element in an aircraft. To solve these problems, a student needs a comprehensive fundamental knowledge in the field of structural materials, manufacturing technique, processing methods, strength of materials, which he receives during his studies at a higher education institution.

It is impossible to imagine highly intelligent production of aviation equipment without the implementation of a whole range of special software products for computer-aided design and engineering analysis, such as MCS Patran/Nastran (Fig. 6) and

Critical load type: "Abuse-300". Critical rupture type - pulling out of the grid material under the shear force

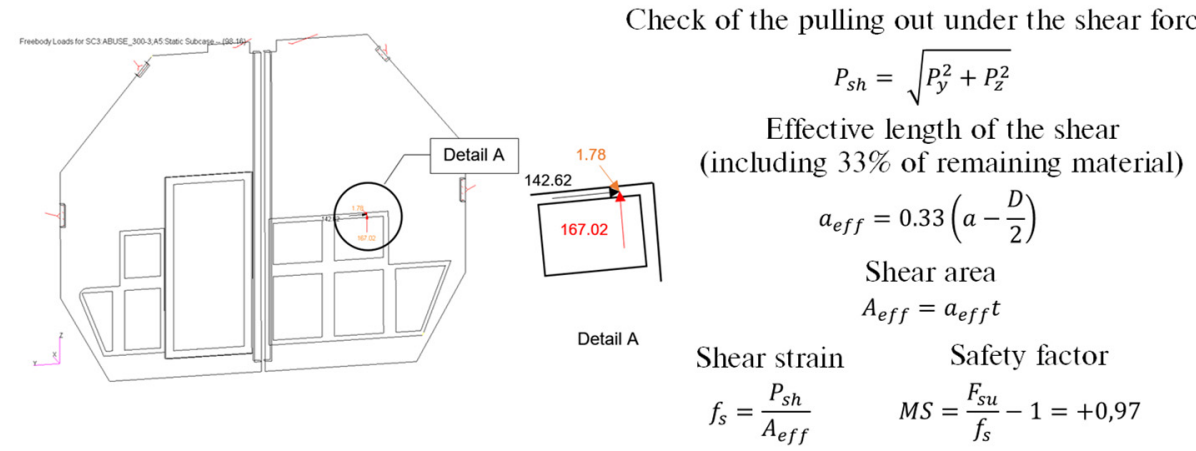

Shear and tension testing of fastening elements and inserted pieces:

$$
R_{T}=\frac{P_{\text {tens }}}{P_{\text {tens,allow }}} ; \quad R_{S}=\frac{P_{\text {shear }}}{P_{\text {shear,allow }}} ; M S=\frac{1}{1.15 \sqrt{R_{t}^{2}+R_{S}^{2}}}-1=+0,05 \quad \text { Inserted pieces: } \mathrm{MS}=+\mathbf{0}, 08
$$

Fig. 5. Fragment of a student's work on modernization of the ventilation grid 


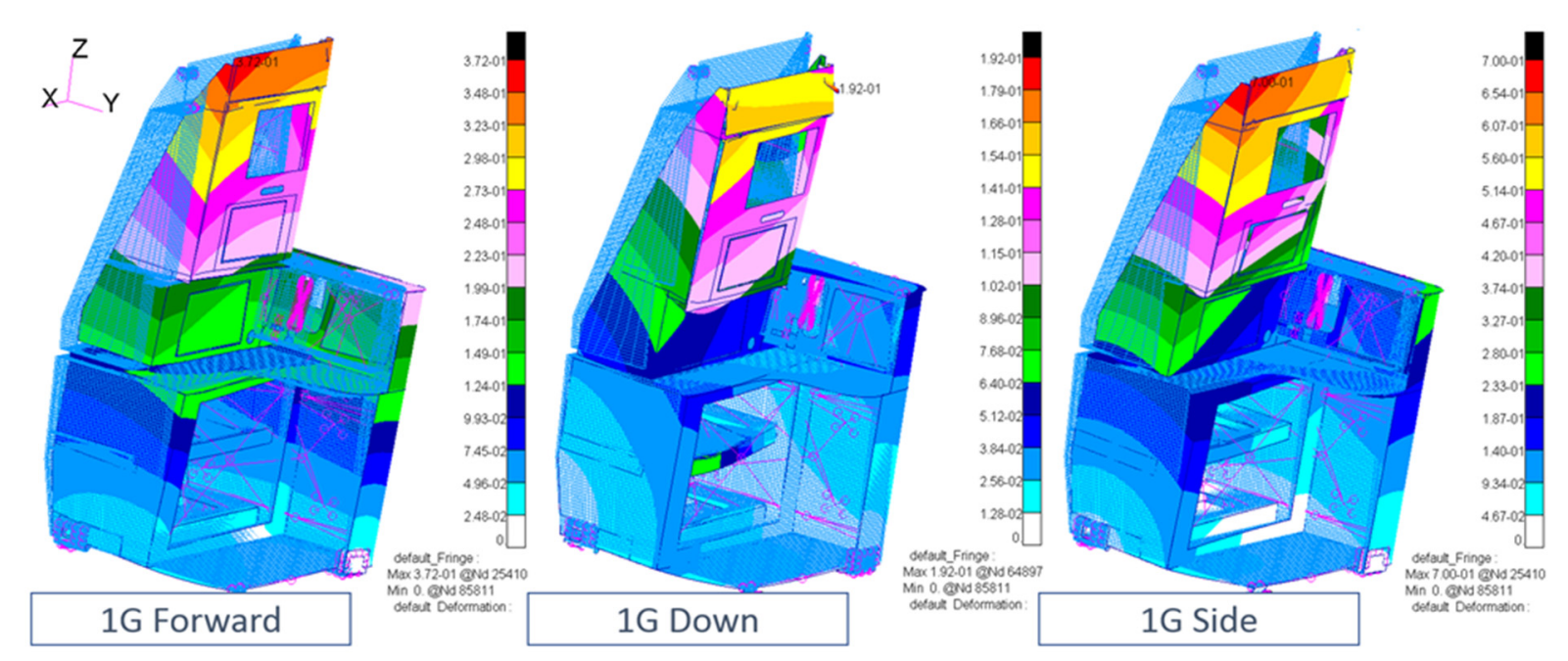

Fig. 6. Example of Patran/Nastran use for determination of the displacement of elements of the flight attendant's workplace under different types of overloads

DS Catia, and many others. These products enable to validate characteristics of an article and identify its weaknesses during the design stage, which significantly improves the quality of engineering services provided by the enterprise, and reduces the time required to manufacture the final product.

The University, as an immediate participant in the dual education system, must take into account the specifics of the partner enterprise when drawing up curricula, and make every effort to ensure that the student can master the necessary software products. While mastering the engineering specialty, a special attention is paid to design paperwork and three-dimensional models. Indeed, on the basis of three-dimensional models of components, it is possible not only to correctly assemble or place parts relative to each other, but also to use these models for calculating the stress-strain state or when determining other parameters which are necessary for subsequent work on the project (Fig. 6).

An integral component of the innovative training of specialists is the involvement of a master's degree student in the scientific work of the graduate department. This component gives the student the opportunity to study more comprehensively the specifics of the scientific topic to which he is involved, to master the methods and techniques of conducting experimental research, to get real skills in planning and conducting an experiment in practice. The work in a research workgroup develops the ability to analyze and process the data obtained, specify goals and formalize tasks, formulate conclusions and present ideas. All these skills develop an engineering brainwork and help to form a specialist in the aircraft building industry. This tendency is rapidly developing within the dual educational program "BOEING UKRAINE - PROGRESSTECHUKRAINE - KPI".

\section{Conclusions}

System analysis of engineering and technological problems of aviation companies of Ukraine showed that the qualification of the graduates does not meet the requirements of high-tech companies.

The main goal of a multi-layer dual education, that was jointly developed by Igor Sikorsky Kyiv Polytechnic Institute, "Boeing Ukraine" and "Progresstech-Ukraine", is to train qualified specialists for the solution of everyday practical and technological tasks that are common for "Boeing Ukraine" and "Progresstech-Ukraine".

Cooperation of Igor Sikorsky Kyiv Polytechnic Institute, "Boeing Ukraine" and "ProgresstechUkraine" was launched in 2012. Joint dual education master's degree "Dynamics and Strength of Machines" was certified by European Network for Accreditation of Engineering Education (ENAEE).

The broadening of the three-level system of dual education offered by Igor Sikorsky Kyiv Polytechnic Institute, "Boeing Ukraine" and "Progresstech-Ukraine" to the multi-disciplinary level has a good potential and will be beneficial not only for the educational institutions but also for the high-tech companies. 


\section{References}

[1] D. Khrapach and H. Krasylnykova, "Comparative analysis of dual education in Germany and Ukraine: Approaches and models," Comp. Prof. Pedagog., vol. 9, no. 3, pp. 8-15, 2019. doi: 10.2478/rpp-2019-0023

[2] T. Deissinger, "The German dual vocational education and training system as 'good practice'?," Local Econ.: J. Local Econ. Pol. Unit, vol. 30, no. 5, pp. 557-567, 2015. doi: 10.1177/0269094215589311

[3] V. Józsa, "Dual education models as elements of corporate embeddedness in Hungary," in Proc. Engineering for Rural Development, Jelgava, Latvia, 24-26 May 2017, pp. 982-987. doi: 10.22616/ERDev2017.16.N204

[4] Š. Kozák, "Multidisciplinary approach and dual education in control engineering for mechatronics," IFAC-PapersOnLine, vol. 49, no. 6, pp. 52-56, 2016. doi: 10.1016/j.ifacol.2016.07.152

[5] L. Didukh et al., "EXPERIENCE OF PREPARATION OF COMPETITIVE SPECIALISTS IN THE CONDITIONS OF THE IMPLEMENTATION OF DUAL EDUCATION IN HIGH EDUCATION INSTITUTION,” Sci. J. Pol. Univ., vol. 33, no. 2, pp. 129-135, 2019. doi: 10.23856/3314

[6] A.Yu. Pleshakova, "Germany's dual education system: The assessment by its subjects," Educ. and Sci. J., vol. 21, no. 5, pp. 130-156, 2019. doi: 10.17853/1994-5639-2019-5-131-157

[7] M. Pogatsnik, "Dual education: The win-win model of collaboration between universities and industry," Int. J. Eng. Pedagog. (iJEP), vol. 8, no. 3, pp. 145-152, 2018. doi: 10.3991/ijep.v8i3.8111

[8] T.D Ishchenko and A.B Tchaykovska, "Will the dual education be the light at the end of the tunnel?," in Proc. Int. Scientific and Practical Conf. "The Dual Form of Education as One of the Models of Improving the Quality of Specialists Training for the Agrarian Sector of The Economy of Ukraine”, Kyiv, Ukraine, 17 October 2019, pp. 4-9.

[9] MES PROPOSES DRAFT REGULATIONS ON THE DUAL FORM OF HIGHER EDUCATION AND PROFESSIONAL PREHIGHER EDUCATION FOR PUBLIC DISCUSSION [Online].

Available: https://mon.gov.ua/ua/news/mon-proponuye-dlya-gromadskogo-obgovorennya-proyekt-polozhennya-pro-dualnuformu-zdobuttya-vishoyi-ta-fahovoyi-peredvishoyi-osviti

[10] How dual education will help solve the problem with personnel in Kropyvnytsky [Online].

Available: https://gre4ka.info/statti/58838-yak-dualna-osvita-dopomozhe-vyrishyty-problemu-z-kadramy-u-kropyvnytskomu

[11] Regulation on the dual form of higher education in Igor Sikorsky Kyiv Polytechnic Institute, 2020 [Online]. Available: https://osvita.kpi.ua/sites/default/files/downloads/Положення\%20про\%20дуальну\%20\%20освіту.pdf

[12] M.M. Gladskyy and K.S. Barandych, "Experience in professional engineers training in a form of dual education," in Proc. Int. Scientific and Technical Conf. "PROGRESSIVE TECHNICS, TECHNOLOGY AND ENGINEERING EDUCATION", Kyiv, Ukraine, 6-9 October 2020.

\section{О.В. Стєпін, І.А. Гришко}

\section{СИСТЕМА ДУАЛЬНОЇ ПІДГОТОВКИ ІНЖЕНЕРНИХ КАДРІВ ДЛЯ НАУКОЕМНИХ ПІДПРИЄМСТВ І ВИСОКО- ТЕХНОЛОГІЧНИХ ГАЛУЗЕЙ УКРАЇНИ}

Проблематика. Нині є невідповідність підготовки висококваліфікованих інженерних фрахівців вимогам високотехнологічного виробництва України для високотехнологічних компаній.

Мета дослідження. Розробити трирівневу систему дуальної освіти КПІ ім. Ігоря Сікорського й авіаційних компаній "Воеing Ukraine” i “Прогрестех-Україна”, зорієнтовану на підготовку спеціалістів для вирішення конкретних інженерних і технологічних задач вищезазначених компаній.

Методика реалізації. Аналіз вдалої співпраці КП ім. Ігоря Сікорського й авіабудівних компаній "Boeing Ukraine” i “Прогрестех-Україна" щодо реалізації концепцій здобуття вищої освіти за дуальною формою навчання.

Результати дослідження. Показано, що впровадження дуальної форми здобуття вищої освіти, заснованої на поєднанні навчальної компоненти з реальною інженерно-конструкторською діяльністю великої авіабудівної компанії, дає можливість задовольнити потреби ринку праці у висококваліфікованих авіаційних інженерах й у фахівцях суміжних спеціальностей для високотехнологічних компаній. Показані переваги дуальної форми інженерної освіти для кожного з учасників процесу. Зазначено, що реалізація цієї форми здобуття вищої освіти повинна мати трирівневий характер, де ролі викладача університету й інженера-конструктора авіаційної компанії як невід'ємним складникам навчального процесу приділено особливу увагу. На прикладі співпраці КПІ ім. Ігоря Сікорського й авіабудівних компаній "Boeing Ukraine " і “Прогрестех-Україна" показано вдалу реалізацію концепцій здобуття вищої освіти за дуальною формою навчання.

Висновки. На підставі системного аналізу інженерних і технологічних проблем авіабудівних компаній України встановлено невідповідність рівня кваліфікації інженерних кадрів - випускників вищих навчальних закладів України вимогам високотехнологічних компаній. Розроблена трирівнева система дуальної освіти КПІ ім. Ігоря Сікорського й авіаційних компаній "Boeing Ukraine" i "Прогрестех-Україна" зорієнтована на підготовку спеціалістів для вирішення конкретних інженерних і технологічних задач компаній "Boeing Ukraine" та "Прогрестех-Україна". Співпраця КПІ ім. Ігоря Сікорського та компаній "Boeing Ukraine" та "ПрогрестехУкраїна" розпочалася в 2012 р. Відтоді понад 130 випускників КПІ стали інженерами цих компаній. Спільна магістерська програма дуальної підготовки "Динаміка і міцність машин" отримала акредитацію Європейської мережі акредитації інженерної освіти (European Network for Accreditation of Engineering Education, ENAEE). Розширення трирівневої системи дуальної освіти КП। 
ім. Ігоря Сікорського й авіаційних компаній “Boeing Ukraine” і “Прогрестех-Україна” дуальної освіти до рівня мультидисциплінарної має великі перспективи та буде вигідним як для навчальних установ, так і для промисловості.

Ключові слова: дуальна форма здобуття вищої освіти; система дуальної підготовки; заклади вищої освіти; авіаційні інженери, високотехнологічне виробництво.

\section{А.В. Степин, И.А. Гришко}

\section{СИСТЕМА ДУАЛЬНОЙ ПОДГОТОВКИ ИНЖЕНЕРНІХ КАДРОВ ДЛЯ НАУКОЕМКИХ ПРЕДПРИЯТИЙ И ВЫСОКО-} ТЕХНОЛОГИЧНЫХ ОТРАСЛЕЙ УКРАИНЫ

Проблематика. Сейчас есть несоответствие подготовки высококвалифицированных инженерных специалистов для высокотехнологичных компаний требованиям высокотехнологичного производства Украины.

Цель исследования. Разработать трехуровневую систему дуального образования КПИ им. Игоря Сикорского и авиационных компаний "Boeing Ukraine" и “Прогрестех-Украина", ориентированную на подготовку специалистов для решения конкретных инженерных и технологических задач вышеуказанных компаний.

Методика реализации. Анализ успешного сотрудничества КПИ им. Игоря Сикорского и авиастроительных компаний "Boeing Ukraine" и “Прогрестех-Украина" в плане реализации концепций получения высшего образования по дуальной форме обучения.

Результаты исследования. Показано, что внедрение дуальной формы при получении высшего образования, которая основана на сочетании образовательного компонента с реальной инженерно-конструкторской деятельностью крупной авиационной компании, дает возможность удовлетворить потребности рынка труда в высококвалифицированных авиационных инженерах и специалистах смежных специальностей, востребованных в высокотехнологичных компаниях Показаны преимущества дуальной формы инженерного образования для каждого участника образовательного процесса. Отмечено, что реализация такой формы получения высшего образования должна носить трехуровневый характер, где роли преподавателя университета и инженера конструктора авиационной компании, как неотъемлемым компонентам учебного процесса, уделяется особое внимание. На примере сотрудничества КПИ им. Игоря Сикорского и авиастроительных компаний "Вoeing Ukraine” и “Прогрестех-Украина" показана успешная реализация концепций получения высшего образования в соответствии с дуальной формой обучения.

Выводы. Системный анализ инженерных и технологических проблем авиастроительных компаний Украины показал несоответствие уровня квалификации инженерных кадров - выпускников высших учебных заведений Украины требованиям высокотехнологичных компаний. Разработана трехуровневая система дуального образования КПИ им. Игоря Сикорского и авиационных компаний "Boeing Ukraine" и “Прогресстех-Украина", которая ориентирована на подготовку специалистов для решения конкретных инженерных и технологических задач свойственных компаниям "Boeing Ukraine" і "Прогресстех-Украина". Сотрудничество КПИ им. Игоря Сикорского и компаний "Boeing Ukraine" и “Прогресстех-Украина" стартовало в 2012 году. С этого времени более чем 130 выпускников КПИ стали инженерами этих компаний. Совместная магистерская программа дуальной подготовки “Динамка и прочность машин" получила аккредитацию Европейской сети аккредитации инженерного образования (Еuropean Network for Accreditation of Engineering Education, ENAEE). Расширение трехуровневой системы дуального образования КПИ им. Игоря Сикорского и авиационных компаний "Вoeing Ukraine" и “Прогресстех-Украина" до уровня мульти-дисциплинарной имеет большие перспективы и будет выгодной как для образовательных учреждений, так и для промышленности.

Ключевые слова: дуальная форма получения высшего образования; система дуальной подготовки; учреждения высшего образования; авиационные инженеры; высокотехнологичное производство.

Рекомендована Радою

Механіко-машинобудівного інституту

КПІ ім. Ігоря Сікорського
Надійшла до редакції

29 жовтня 2020 року

Прийнята до публікації 10 грудня 2020 року 